\title{
A spectacularity concept in modern philosophy
}

\author{
Nataliia Kolodii $^{1, \mathrm{a}}$, Ekaterina Khomyakova ${ }^{1}$, Vyacheslav Kolodii ${ }^{1}$, and Yuliya Chayka ${ }^{1}$ \\ ${ }^{1}$ National Research Tomsk Polytechnic University, 30, Lenin Street, Tomsk 634050, Russian Federation
}

\begin{abstract}
The paper focuses on the interpretation problem of the concept of spectacularity in modern philosophy. The particularities of different conceptions of spectacularity are analyzed and the special attention is paid to its role in the development of the modern society. The main objective of the article is the critical analysis of different theories of philosophers and cultural experts in the context of the spectacularity phenomenon. The research applies the methods of the systematic approach and contextual analysis. The novelty of the paper lies in the formation of the strengths and weaknesses of the spectacularity concepts and in the development of certain principles of the interdisciplinary study of the phenomenon. This research could be of interest for professionals working in the field of sociology of culture and philosophy of culture.
\end{abstract}

\section{Introduction}

Today transformations that affect absolutely all spheres of culture are conceptualized systematically and consistently within different paradigmatic borders, using a multidisciplinary approach. We consider it to be topical to analyze the transformation of the communications within the framework of the philosophical and cultural approach focusing on the idea of spectacularity.

\section{The main part}

There are philosophical ideas, which relevance in scientific communities at the time of their articulation does not seem obvious. In modern researches on spectacularity the principles of the Situationist analysis that are worded in the book of Guy Debord "Society of the Spectacle" [1] are actively used. In Russia at the time of publication, the study did not attract much attention of the scientific community, although the study generated a wave of the critical publications caused by suspiciousness in relation to discourses of leftist-minded western intellectuals.

But as time passed, the interpretation of Debord became a paradigm for many social critics and theorists. Today the problems of spectacularity, visuality, contemporary forms of social protest and engagement of young people in these movements are already generating detailed substantive discussion.

There is no such a tendency as rigid conceptualization of a spectacularity phenomenon in the modern philosophy today in spite of the fact that in a culturological and philosophical discourses a certain

\footnotetext{
$\bar{a}$ Corresponding author: kolna@tpu.ru
}

systematization of the approaches and theories takes place even more often, so far as we are talking about spectacularity of any subject or phenomenon. The origins of this concept can date back to the West European culture of Modern times of the XVII-XIX centuries. In the French language the word "spectaculaire" appeared in the beginning of the XX century, replacing the earlier adjective "spectaculeux" meaning "solemn", "reminding performance", "excessively theatrical" [2].

The analysis of works of foreign culture experts and philosophers allows us to identify several specific types of spectacularity, for example promoting concentration and immersion in work; the carnival; the performative; determining sports, fashion, policy. No matter what type of spectacularity it is, it refers to a material cover of a show (scenery, picture, music, dances etc.), but mostly means the influence which all these effects make on the viewer.

In social and philosophical literature special attention is devoted to the following subjects: war as performance, performance and mass media, post-colonial performances, subcultures and performance, the body as a performance, the Internet and web performances, etc. $[3,4,5,6]$. In modern theoretical ideas of the philosophers, culture experts, art and theater critics of the West, the opinion on carnival, gaming, theatrical nature of social life and ways of its' perception is widespread.

When mapping the political vector, social theorists subject the following to a special reflection: public and virtual space of a social protest, repertoires of alternative projects; creation of temporary urban "autonomous zones", collective dramatic art of overcoming depression, tactics of microresistivity of authorities, as 
well as many other manifestations of "vital policy" (E. Giddens), characterized by a special dramatic art, entertainment, staging [3].

If we turn to the group of sources, which initiates a discursive discussion of the spectacularity, it is necessary, first of all, to pay attention to the classification of M. Mead, according to which there are three types of cultures, each of them has different occurrence of sociocultural intergenerational interaction. Prefigurative cultures are oriented to the future and reflect the times in which we live. [7] It allows us to prove why all the stage effects in the modern social space and all dramatic art "life practices" can be analyzed as an example of socio-cultural life of young people. Probably, it is possible to disagree only with the recognition that prefigurative culture in modern society has taken a dominant position. There is no doubt in the fact that this modality will plot one of the major vectors of the civilization development. If to acknowledge the validity of the thesis which we described above, it is quite natural, and it correspond to the logic of the research.

One more group of sources includes the texts meaningfully related to the "Dialectic of Enlightenment" by M. Horkheimer and T. Adorno, who postulated totality of the culture industry in contemporary society and showed that "entertainment becomes prolongation of labor in the late capitalism", and "art is only a kind of the goods manufactured, delivered, equated to the industrial production, on sale and replaceable" [8, page 264]. And, for example, Das Passagen-Werk of W. Benjamin showed the modern interpretation of the phenomenon of perspective modernity - reality (and the most characteristic feature of) which is in the consumption of spectacle (illusions) in exchange or in addition to material benefits [9]. G. Lukacs's concept [10] is also very important: the interpretation of "spectacle" offered by Debord follows from the opposition of formation and praxis [1].

As a matter of interest, only four of Debord's theses have got very extensive development in the socio-critical philosophical and cultural literature. They are: thesis 10: "The Spectacle is "affirmation of all human life, namely social life, as mere appearance" [15], thesis 6: "The Spectacle...occupies the main part of the time lived outside of modern production" [15]. And there is one more fairly simple statement formulated in thesis 16 : "The Spectacle subjugates living mento itself to the extent that the economy has totally subjugated them" [15]. And, finally, thesis 30 is "The alienation of the spectator from the profit of the contemplated object (which is the result of her/his own unconscious activity) is expressed in the following way: the more she/he contemplates, the less she/he lives; the more she/he accepts recognizing herself/himself in the dominant images of need, the less she/he understands her/his own existence and desires. The externality of the spectacle in relation to the active person appears in the fact that her/his own gestures are no longer hers/his but those of another's who represents himself/herself to her/him. This is why the spectator feels nowhere when at home, because the spectacle is everywhere" [15]. It is even more significant that the basis for its development has been drawn from the different ideological discourses: Advanced capitalism, Consumerism, Mainstream. But it happened in a variety of forms such as Public relations, Tabloid journalism, Dumbing down, Framing.

Against this background, there arises the demand for an increasingly high level of spectacularity. It permeates many areas of culture, everyday life and sport. For example, in football, this requirement changes the style of the game itself, where it is showiness that begins to be appreciated but not effectiveness. A significant place in this process belongs to journalism, which sets up the perception of viewers in a certain way, and photography that captures the most "spectacular" moments of the match. In social terms, the football craze covers all the wider community, and the behavior of the stadium audience begins to serve as one of the indicators of "the mood of the masses", it means that football with its special spectacularity is within the political scope. Such a synthesis of spectacularity and real existence of cultural phenomena gives birth to the absolute otherness of all the content of culture and sociality.

In response to Debord's work in modern cultural studies not only the idea spectacularity, which permeates all life practices, has began to be discussed but also such an actor of contemporary urban cultural field as a flâneur. T. McDonough, a contemporary commentator of Debord's ideas, writes in his article entitled «Situationist Space»: Operating in the realm of everyday life, the dérive constitutes an urban practice that must be distinguished, first, from "classic notions of the journey and the walk," as Debord noted in "Theory of the Dérive." The dérive was not simply an updating of nineteenth-century flânerie, the Baudelairean strolling of the "man in the crowd." This is not to say that they do not share some characteristics: both the flâneur and the person on the dérive move among the crowd without being one with it» [16]. Describing this type of a city dweller, the researcher concludes, that figures of such kind could in some degree shape the scopic regime of modernity: «But whereas the flâneur's ambiguous class position represents a kind of aristocratic holdover (a position that is ultimately recuperated by the bourgeoisie), the person on the dérive consciously attempts to suspend class allegiances for some time. This serves a dual purpose: it allows for a heightened receptivity to the "psychogeographical relief" of the city as well as contributing to the sense of "dépaysement," a characteristic of the ludic sphere. For the situationists, however, the dérive was distinguished from flânerie primarily by the critical attitude toward the hegemonic scopic regime of modernity» [16]. Gradually this issue began to be discussed as a problem of Iconization processes and urban spaces $[17,18,19,20]$. Jeffrey Alexander formulated his ideas of visuality, performance and spectacularity of modern entertainment culture in the following principles:

- Icons are material surfaces configured (aesthetically formed) in a such manner that their experience generates collective reactions and feelings.

- Iconization processes are some events and practices leading to the emergence of iconic surfaces. 
- Pictures are the signifying, or representing surfaces, some of which are able to intensify iconic effects (not all depictions, or signifying surfaces are iconic ones) and (re)present images.

- An image is a meaningful whole, accessible exclusively through sensual experience and hence (re)presented by icons and pictures (Of course, the question remains: how does language contribute to forming images and social icons?) [21].

It is now gradually happening that elements of the show, demonstartion, representation sideline pragmatics. Even political rallies lose their intellectual functions (discussion, argument, explanation, etc.) and turn into the performance, the degradation of the public sphere takes place: the citizen becomes a spectator, a viewer who is watching the action in which she/he does not participate. Of course, politics as such needs some spectacularuity, but if it starts to replace it completely, then one could talk about the changing of the type of a society. Such context of the development of the society sets the whole program of «non-spectacular art » which is thoroughly permeated with the spirit of the avantgarde. The avant-garde poetics evolves from theming of the autonomy of art and its expressive means to overcoming the boundaries between art and non-art (consciousness and existence, sign and object perception and representation, and so on) to the production of the identity of moments between the two. This can be overcome in various ways: at the level of the "revolution of the imagination" and intensification of life experience (Surrealists) or at the level of the dissolution of art in the production of "new life", building a "monistic universe" on the basis of industrial production and collective property (for constructivists). But all of these programs require the autonomy of art as its prerequisites, provided with a system of art institutions, and the existence of borders between the signifier and the signified, the sign and the object. It is possible to consider the project of "nonspectacular art" as the reaction to the « excessive spectacularity » and the mass medial obsession suffered by the art in the $90 \mathrm{~s}$, and also in the context of the spectacularity paradigm of culture as a whole. There exist many supporters of both positions among the adherents of the social critical theory. The important thing here is what development strategy of the artistic, communicative and cultural practices of the researchers seems to be the most promising: either it is the escape from reality or achievement of the identity man-action, man-behavior and thus eliminating the splitting of the existence of two incarnation, eliminating the dichotomy between art and life [16].

In the present situation there arises the strategy of building a "closed", esoteric artistic context and thus a closed artistic community as opposed to the totality of globalized "society of the spectacle". The object, or rather, the situation which obtains aesthetic value within this context, is not read from the outside and does not stand out from the everyday background. "Nonspectacular art" is immanent to the order of things ", that is why the goals of this art are always "local and specific." This update reveals the basic problem, which questions now existing nonspectacular art: how to avoid the separation from reality and at the same time maintain a critical distance? If to admit that "none-spectacular art" is politically active and critical, it is necessary to take some kind of transcendental position for the criticism of the society. Such transcendental position is possible inside this society by means of cultivation of "nonspectacular islands" in the midst of the universal obsession with "the demon of images." In this connection, it is necessary to raise a fair question the old question of engaged art. All this leads to the conclusion that Debord's ideas are still relevant, and not only in terms of Situationist ideas but also in terms of understanding the culture as a whole. A visual appeal or spectacularity as an aesthetic category refers to visual, monumental, total. It meets the needs of the modern spectator, formulated by Thomas Krens, the Director of the Foundation of the Guggenheim Museum, and this major need is "to get the total, serial, the increasing intensity of the experience" [17].

Now it is possible to add this to the ideas of $G$. Schultze [11].

G. Schultze considers aestheticization as the factor structuring sociocultural fabric in the developed world. According to Schultze, orientation of a person towards self does not become the reason of social dissociation and disintegration of traditional social relations, because collective experiences are very powerful. On the contrary, it is the reason that people with the internal orientation are more likely to take part in collective events, since we are talking about the type of experiences that people can only experience together.

Interpretation of aesthetical experiences as something ephemeral and unreal is peculiar to the left tradition, being in which W. Benjamin, G. Debord, and also Marxist philosophers W. Fritz and F. Jameson criticize both democratization of aesthetic, and theatricality of modern society.

J. Baudrillard relating to the left model defines ephemeral and unreal in life of the modern person as a term simulacra. Simulacra by Baudrillard are signs or not self-identical phenomena referring to something else, so that they are simulative. Simulation is a basis of hyper-reality, which persistently replaces reality in today's society. We see here an echo of the concept of the Russian theorist of culture, M. Bakhtin, in which there is much opposition of official and folk culture, and also it admits existence of traditions, values, which are in the "vertical" (absolute recognition of the hierarchy of values), where there are norms and regulations of mimesis which carries mainly silent people.

Unlike the left critics of a mass aestheticization, (for example, idem Benjamin, who believed that aestheticization comprises blocking of reflexive ability of the subject) G. Schultze declares that on the contrary it increases reflexivity. Schultze points to the direct connection between the extension of opportunities for individual choice associated with the democratization of society and the aestheticization of life. In this approach, the idea of the American authors, B. Joseph Pine II, James H. Gilmore, in the work "The Experience Economy" [12], where the experiences received by the phenomena that Debord criticizes appear not as a feature 
of the strategy of the modern media industry. Quite the opposite they appear as a radically new social phenomenon, affecting the socio-cultural transformation of the whole of modern society and are of interest. Consequently, followers of aestheticization tell about the spectacularity, which find its place in "experience society" with the dominance of the "experience economy". Here hierarchies, regulatory provisions and systems of values are absent. The person here becomes an accomplice in production of experiences, sets parameters of the desired dramatized tradition and actively participates in production of dramatic art of all actions, from production to consumption.

Analysis of the theoretical foundations of spectacularity allowed us to point out the opposing views of this phenomenon. Basically, our thoughts were stimulated by discussion that the phenomenon of the aestheticization of daily occurrence is introduced in today's reality. We have based our arguments on the fact that the most significant in this aestheticization is that, according to Schulze, it changes "internal orientation" of the subject. But according to Benjamin it promotes to a fight of two modalities of basic social processes: on the one hand, increasing individualization (subjectivation associated with aesthetic experience, this also is the increasing individualization); on the other hand, "the increasing organization of the masses", resulting in the ability of the system to manipulate "atomized" individuals.

Thus, these two approaches help to separate key features that are associated with the Schultze's thesis or the Benjamin's thesis. Nevertheless, we can also speak about existence of the social ambivalence, which is showed in a "fight" of two modalities of social processes and the phenomena: on the one hand, increasing individualization caused by an aestheticization, on the other - the increasing "organization of the masses". So it is possible to define one more, intermediate point of view, which demonstrates various aspects of the spectacularity, shows all "pros" and "cons" of this endless process of representation and image making. This could include a whole nonspectacular art represented as reaction to an excess hypertrophied spectacularity, obsession of mass media and glamour. Here the movements opposing the logic of glamor finds its place, which is against submission to what they see as a substitute for real depicted, united by the general idea of the rebellion authenticity against virtuality.

\section{Conclusion}

Thereby we tried to develop the basic ideas of the institutionalization of the aesthetics of modern spectacularity activity. We are inclined to the idea characterizing the trends of modern society, which general sense is that today the spectacularity forms of existence in the information world, which facilitate creation of a zone for "collective" social experiences, are most successfully assimilated.

Thus, spectacularity studied as a constant of the modernity, a mental model of society, the main form of receiving and exchanging of information, a way of communication, perception of reality and world around interpretation, and also a basic mode of realization of modern life practices allowed us to find out the fundamental bases of modern culture. They also revealed the principles of its architectonic, including the experience which we gain in this spectacularity. Based on this analysis, it seems possible to state that the spectacularity is an important cultural phenomenon in contemporary reality. At the present stage the cultural component moves to the forefront and starts predetermining all others: social, economic, political, etc. This cultural component at this stage takes the shape of spectacularity.

\section{References}

1. G. Debord, Society of the Spectacle (Moscow: Opustoshitel, 2012)

2. R.Martin, R., Quand le merveilleux saisit nos sens: spectaculaire et féeries en France (XVIIe-XIXe siècle). Sociétés et representations, www.univparis1.fr/centres-de-recherche/isor/activite/societesrepresentations/n-31-le-spectaculaire-a$\underline{\text { loeuvre/resumes-n-31-le-spectaculaire-a-loeuvre }}$ (2011)

3. A. Fetzer, The Pragmatics of Political Discourse: Explorations across cultures (Philadelphia: John Benjamins Publishing, 2013)

4. W. Bublitz, A. Hübler, Metapragmatics in Use (Philadelphia: John Benjamins Publishing, 2007)

5. M. Talbot, Media Discourse: Representation and Interaction (Edinburgh University Press, 2007)

6. J. Rancière, Le spectateur émancipé (Paris: La fabrique editions, 2008)

7. M. Mead, Culture and Commitment: A Study of the Generation Gap (N.Y., 1970)

8. M. Horkheimer, Adorno, T., Dialectic of Enlightenment (Moscow: Medium, 2002)

9. W. Benjamin, Das Passagen-Werk. Band 1. Hg. Rolf Tiderman (Frankfurt am Main: Suhrkamp, 1987)

10. G. Lukach, Monitoring of public opinion: economic and social changes, 1(69), (2004)

11. G. Schulze, Die Erlebnisgesellschaft. Kultursoziologie der Gegenwar (2.Aufl. Frankfurt. N.Y.: Campus Verlag, 2005).

12. J. B. Pine, J. Gilmore, The Experience Economy: Work Is Theater \& Every Business a Stage (Harvard Business School Press, 1999)

13. A. Fetzer, G. Lauerbach, Political Discourse in the Media (Philadelphia: John Benjamins Publishing, 2007)

14. The politics of Unsustainability: Eco-Politics in the Post-Ecologist Era, Routledye Research in Environmentak Politics (2013)

15. G. Debord, The Society of the Spectacle, translation by Fredy Perlman and Jon Supak (Black \& Red, 1970; rev. ed. 1977). Online at Library.nothingness.org 
16. T. McDonough, Situationist Space// Guy Debord and the situationist international: texts and documents (Edited by Tom McDonough. London: MIT, 2002)

17. J. C. Alexander, Performance and Power (First Edition, Yale University Press, 2011)

18. J. C. Alexander, Obama Power (with Bernadette Jaworsky) (Polity Press, 2014)

19. J. C. Alexander, Theory, Cul. \& Soc. no., 1 (31), 324 (2014)

20. R. Birla, Compar. Stud. of South Asia, Africa and the Middle East, 35, 3 (2015)

21. I. Inishev, Visual Representation of Urban Spaces: Iconic Strategies of (Post)-Modern City (School of Cultural Studies, HSE)

22. I. Nahon-Serfaty, Intern. Journal of Cult.Stud., 18 (2015)

23. Germano Celant, Moscow Art Magazine, 2, 15-18 (1993)

24. R. Krauss, The Cultural Logic Of The Late Capitalist Museum, 54, (1990)

25. C. Bishop, Participation and Spectacle: Where Are We Now? Living As Form: Socially Engaged Art From 1991-2011 (Cambridge, MA, 2012)

26. Guy Debord and the situationist international : texts and documents / edited by Tom McDonough (Massachusetts Institute of Technology, 2002) 